\title{
Where Does Child Language End and Adolescent Language Begin?
}

\section{Summary \\ Introduction}

Adolescent language is a form of linguistic self-identification expressed most vividly in oral and written speech of adolescents' mutual communication in informal situations and it varies depending on sociological factors (speaker's gender, age, education, belonging to a specific group of youths etc.). Adolescents' age group nowadays includes individuals between 13 and 30.

\section{Aim of the study}

Aim of this article is to analyse the borderline separating child's language and adolescent's language, as well as to determine the differences in features of both language varieties.

\section{Materials and methods}

The article contains materials on researches of child's and adolescent's language in Latvia and Germany, as well as the results acquired during project "Language individualities of age groups in Latvia: linguistic, social and cultural aspect" of 2008 State research programme "Latvian Studies: research on history, language and culture" carried out in research centre of child's language at the Riga Teacher Training and Educational Management Academy.

\section{Results}

The term 'adolescents' has failed to have a uniform definition up to now. This term includes biological and social aspect, which are understood differently in different eras and cultures: adolescence in the cycle of each individual begins with puberty and ends when the individual has found his personal and social identity proven by economic and social independence.

In psychology, sociology and linguistics, various opinions rule about the age borderline dividing a child from an adolescent. This causes additional difficulties when analysing the influence of age on language use. Research show that various periods of adolescents' physical and psychic development affect usage changes in language means of expressions at the definite age, for example, it has been concluded that an adolescent's age influences his speech: the older is the adolescent the more his speech resembles adult speech. Such comparison would be necessary to carry out research an child's speech.

\section{Conclusions}

Comparison of features of child's and adolescent's language (use of non-literary vocabulary and vulgarism, making of neologisms, and using vocabulary incomprehensible to adults) lead to be conclusion that the most significant differences of both language varieties are to be found in functions of neologism formation and usage, intentional formation of vocabulary which is incomprehensible to adults and the adults' attitude towards use of one and the same vocabulary in child's and adolescent's speech. Further research should find out what extra-linguistic circumstances facilitate arising of these differences, for example, how school children feel in the society and how these feelings are reflected in speech.

Key words: child's language, adolescent's language, age period border, language use.

\section{Introduction}

Adolescent's language is a form of linguistic self-identification expressed most noticeably in oral and written speech of adolescents' mutual communication in informal situations, and it varies depending 
on sociological factors (speaker's gender, age, education, belonging to a specific group of youths etc.). Adolescents' social group traditionally includes individuals of the age between 13 and 30 .

Reviewing the first book in Latvia which is dedicated only to language characteristics at the age of adolescents - monograph “Jauniešu valoda" (Adolescents' Language) by V. Ernstsone and L. Tidriķe, Austra Gaigala turns attention to aspects which could cause uncertainty, for example, how to separate child's language from adolescent's language:

"Unclear is the border dividing a child from an adolescent. Namely, the book stresses that adolescent language differs both from child language and from adult language, but it is clear that the mentioned age of 13 is a too arbitrary division. Likewise it is clear that child as a social being uses words of non-codified language heard in peers' company and from older conversation partners. A question arises - what are the conditions and objectives of the child's choice for means of expression separating them from functions of adolescent's language? Would a child's wish to be noticed by a less heard or completely new and special word be different from the adolescent's efforts to use expressions for attracting attention?"

\section{Aim of the study}

Objective of this article is to try to find answers to issues raised by the reviewer regarding differences in child's and adolescent's language. At first we will analyse when an individual is no longer seen as a child, namely, we will find whether a precise age boundary can be drawn between "child" and "adolescent". Further, we will review the similarities and differences of child language and adolescent language.

\section{Materials and methods}

The article contains materials on research an child and adolescent language in Latvia and Germany, as well as the results acquired during project "Language individualities of age groups in Latvia: linguistic, social and cultural aspect" of 2008 State research programme "Latvian Studies: research on history, language and culture" carried out in research centre of child's language at the Riga Teacher Training and Educational Management Academy.

\section{Results}

It should be stressed that the term adolescent has failed to have a uniform definition developed until now. This term includes biological and social aspect, which is understood variously in different eras and cultures (Ferchhoff 1999, 67; Cherubim 1986, 88). The following definitions are significant for study of adolescent's language:

- adolescents' age in the cycle of each individual begins with puberty ${ }^{1}$ (approximately at the age of 13) and ends when the individual has found his personal and social identity proven by economic (employment, income) and social independence (independent living, establishment of family and others) (Schäfers 2001, 18);

- adolescents age includes individuals at the age of approximately 13 to 25 (Ferchhoff, Neubauer 1997, 109; Ferchhoff 1999, 68; Remschmidt 1992, 3; Bernart 1998, 352; Hurellmann 1998, 253; Zimmermann 2000, 146).

We will review the undermost border of this division, namely, the age when a child becomes an adolescent. It should be stressed that neither in the division, nor in the used terminology, unanimity can be found (see Table 1). For example, German sociologist B. Schäfers stresses the age of 13 as the beginning of puberty (Schäfers 2001, 19). In Latvian psychology (also pedagogy), adolescence starts at the age of 10: individuals of 11/12 until 15/16 should be regarded as adolescents (Svence 1999, PTSV 78, 143). On 
analysing psychology of adolescents' age development, German psychologist H. Fend separates five stages: preadolescence (age of 10-12), early adolescence (age of 13-15), intermediate (real) adolescence (age of 15-17), late adolescence (age of 18-20) and post-adolescence (age of 12-25) (Fend 2000, 91). Further, some scientists stress gender differences in an adolescents' age, for example, for girls, puberty begins at the age of 12-14, in turn for boys, puberty begins at the age of 14-16 (Zimmermann 2000, 146; Kasten 1999, 15). When speaking of adolescents age, German and other (for example, USA) theory quite often uses term adolescence. G. Svence suggests translating this term as the period of early youth [Svence $1999,120]$, but in such case it is problematic to understand terms preadolescence, post-adolescence and others. Furthermore, German psychology sometimes separates the terms puberty and adolescence: puberty denotes the processes of physical maturity (beginnings of capability to reproduce), in turn the term adolescence actualises the psychic aspects of development [Remschmidt 1992, 2].

Table 1

Age border between the age of children and adolescents

\begin{tabular}{|c|c|c|c|c|c|c|c|c|}
\hline Author/age & 10 & 11 & 12 & 13 & 14 & & 16 & 17 \\
\hline B. Schäfers & & & & \multicolumn{5}{|c|}{ Puberty stage } \\
\hline G. Svence & \multicolumn{5}{|c|}{ Teenagers'stage } & \multicolumn{3}{|c|}{ Adolescents' stage (youth) } \\
\hline H. Fend & \multicolumn{3}{|c|}{ Preadolescence } & \multicolumn{2}{|c|}{ Early adolescence } & \multicolumn{3}{|c|}{ Intermediate (real) adolescence } \\
\hline
\end{tabular}

Sources: Svence, G. 1999; Fend, H. 2000, 91; Schäfers, B. 2001, 19.

An insight in the division of adolescents' age allow adopting the conclusion that it is impossible to determine a precise age boundary between a child becoming an adolescent; further, it should be taken into account that girls and boys may have a different boundary. Moreover, an interesting conclusion arose when analysing replies given by adolescents to a question how old individuals belong to the youth age: the age division varies depending on the age of the respondents. The younger the respondent is, the earlier starts the adolescences. Thus, for example, pupils at the age of 13 are of the opinion that individuals at the age of 13 to 18 belong to the adolescence. In turn, pupils of the $12^{\text {th }}$ grade are of the opinion that individuals at the age of 15 (16) to 20 belong to adolescence.

German linguistics have fixed only two trials to analyse correlation between age and language use at the age of adolescence (see Table 2). In article "From fett to fabelhaft: adolescents' language in language biography", German scientist J. Andrutsopuloss, sees language use in relation to the various stages of the adolescents' age: 1 ) preadolescence (up to the 11th/12th year of life), 2) adolescence (12-19 years) and 3 ) post-adolescence (up to the $25^{\text {th }}$ or even $30^{\text {th }}$ year of life) (Androutsopoulos 2001, 66). E. Neuland, upon analysing the relation of age and language use, divides the adolescents' age in three stages: 1) late childhood, early adolescence (years 10-14), 2) "classical" adolescence, youth (years 15-19) and 3) late adolescence, post-adolescence (years 20-24) (Neuland 2004).

Table 2

Adolescents' age division in study of adolescents' language

\begin{tabular}{|c|c|c|c|c|c|c|c|c|c|c|}
\hline Author/age & 10 & 11 & 12 & 13 & 14 & 15 & 16 & 17 & 18 & 19 \\
\hline J. Androutsopoulos & Pre & esce & & \multicolumn{7}{|c|}{ Adolescence } \\
\hline E. Neuland & \multicolumn{5}{|c|}{ Late childhood, early adolescence } & \multicolumn{5}{|c|}{ "Classical" adolescence, youth } \\
\hline
\end{tabular}

Sources: Androutsopoulos, J. 2001, 66; Neuland, E. 2004. 
The mentioned samples prove that in psychology, sociology and linguistics, various opinions rule about boundary dividing a child from an adolescent. This causes additional difficulties when analysing the influence of age factor on language use. Upon analysing the influence of adolescents interviewed in Latvia on concepts on features of adolescents' language, as well as analysing its use, L. Tidrike has analysed the mutual connections between each year and the adolescents' linguistic attitude, which has helped to find the influence of the adolescents' psychological development on language use more precisely, for example, L. Tidrike's study proved that the crisis of the age of 15 is reflected also in the use of language. The psychological features of the adolescents' age are reflected most vividly exactly at this age (Baacke 1991, 36); furthermore, this age is seen as a bridge from teenagers' years to adolescent's years (conf. Svence 1999), namely, a break in development can be observed at this age, marked by one of crises at the adolescents' age. So, for example, pupils at the age of 15 when compared to other age groups, evaluated various features of adolescents' language as always characteristic to the adolescents language, for example $63 \%$ of pupils from general education schools at the age of 15 are of the opinion that the adolescents' language is more free than the adults' language (Tidrike 2004, 93).

Various periods of adolescents' physical and psychological development affect usage changes in language means of expressions at the definite age, for example, it has been concluded that the adolescents' age influences also his speech: the older is the adolescent the more his speech resembles adult speech (Tidrike 2006, 47). Study of child's language in Latvia is at its beginning (Markus 2008, 143); therefore no research exists on changes of language in the child's speech at various ages. It is possible that regularities can be observed in child's speech between the child's age and the use of the language material, which is characteristic to adolescents. But this aspect in the study of child's and adolescent's language has not yet received the necessary attention in Latvia.

This article will not compare all features of child's language and adolescent's language and functions of use. We will look only at the non-literary layer of vocabulary (jargon) used by children and adolescents, as well as at the features which are more profound at the beginning of the adolescents' age (in adolescents' speech at the age of 13) than at the end of this age: use of vulgarism, creative approach to language material, expressed as neologisms and use of peculiar vocabulary for the function of isolation (see Figure 1).

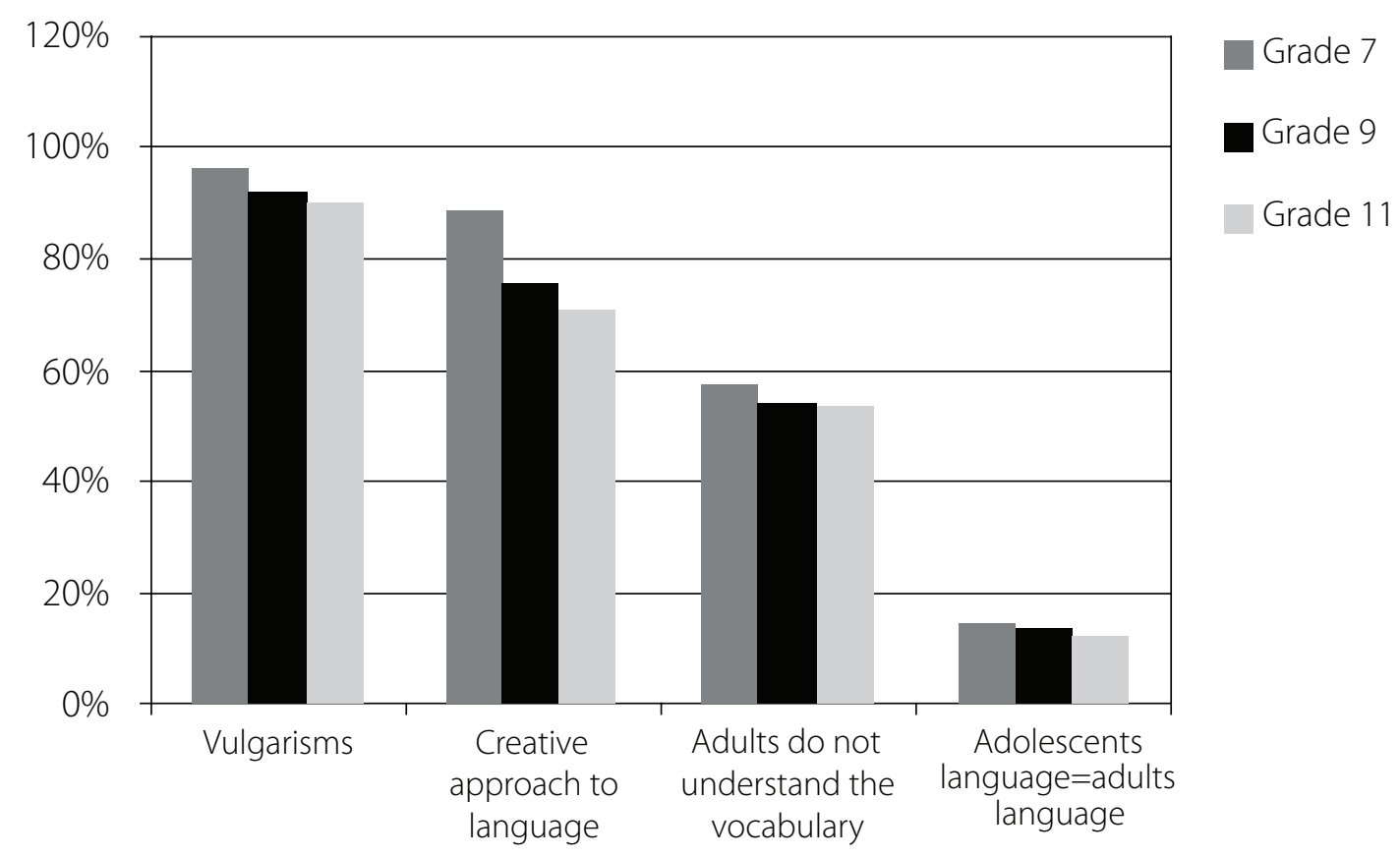

Figure 1

Features of adolescents' language at various stages of adolescents' age 


\section{Non-literary vocabulary}

Researcher of Latvian child's language D. Markus indicates that "jargon is not the most characteristic phenomenon of child's language; however it has been noticed" (Markus 2003, 66). The linguist's observations show that child's jargon usually is borrowed from older brothers and sisters; in turn, the teenagers have a characteristic of their own created jargon, which should be evaluated in relation to the intense urge of self actualization (Markus 2003, 65).

\section{Use of vulgarism}

The author of the article finds an interesting observation in relation to use of vulgarism in child's and adolescents' speech: use of vulgar vocabulary in child communication often causes hilarity among adults; in turn, use of the same vocabulary in adolescent speech is found fault with. Moreover, the adolescent's language has acquired negative reputation due to use of vulgar vocabulary. Here, a sample of life at school: a teacher relates a story to her colleagues as a joke about pupils from younger grades. One of pupils informs the teacher that his classmate has called the teacher a fool. When the teacher shamed the pupil and wished to continue the interrupted class, the same pupil added, "And even more - a whore!" Just imagine how a teacher would react if such remark was said by a pupil from grade 7 !

\section{Neologisms}

Many neologisms by children and adolescents might be regarded as occasionalisms. At the child's age, new words mostly arise as a result of objective difficulties caused to the new person (Markus 2030, $45)$; in turn, at adolescence creation of new words takes place intentionally - language is means with which to stand out with the help of one's imagination. Creativity is the moving force for development of adolescent language, and creative approach to language material is the reason adolescents are regarded as most active users of new words. Many neologisms are used within the scope of one conversation or one group, and these words are doomed to a short life, therefore linguistics sometimes produces an opinion that study of the adolescents' language is unnecessary. On the other hand, it is neologisms coined by adolescents that quite often become fashionable words used by adults, children and mass media, for example, sviests, tusēties, rullēt.

\section{Vocabulary incomprehensible for adults}

This probably is the language feature which significantly separates a child's language from adolescent language - use of vocabulary which is not understood by adults. Children imitate; they try to speak as the adults do - use expressions which have often been hear (for example, Ak, Dievs! - Oh, my God!), as well as to imitate the speech style of adults, tone and intonation (Markus 2003, 60, 61). At the age when the child feels as a grownup (puberty processes), but the adults see him still as a child, individuals start stressing intensely their independence and self-evaluation at thinking, feelings and behaviour, which in turn is reflected in the language: the adolescents wish to belong to some social group and the belonging is expressed in the language as well. Belonging is closely related to isolation; therefore adolescents intentionally create vocabulary and expressions which the adults do not understand (Tidrike 2006, 510).

\section{Conclusions}

The performed comparison allows us to conclude that a precise boundary between the use of child language and adolescent language cannot be drawn. Most significant differences between the two varieties of language are to be found in neologism formation and usage functions, intentional use of vocabulary incomprehensible to adults by the adolescents' language and adults' attitude towards use of one and the same vocabulary by a child and an adolescent. The further researches should to find out what extra-linguistic circumstances facilitate these differences, for example, how pupils feel in society and how these feelings are reflected in language. 


\section{References}

1. Androutsopoulos, J. (2001). Von fett zu fabelhaft': Jugendsprache in der Sprachbiografie. Osnabrücker Beiträge zur Sprachtheorie (62), S. 55-78.

2. Baacke, D. (1991). Die 13-18jährigen: Einführung in die Probleme des Jugendalters. Weinheim und Basel: Beltz, S. 368.

3. Bernart, Y. (1998). Jugend. In: Handwörterbuch zur Gesellschaft Deutschlands (S. 352-361). Hrsg. B. Schäfers, W. Zapf. Opladen: Leske+Budrich.

4. Cherubim, D. (1986). Jugendsprache und Soziolinguistik. In: Neue Entwicklungen der angewandten Linguistik (S. 87-89). Hrsg. W. Kühlwein. Tübingen: Günter Narr.

5. Ernstsone, V., Tidriķe, L. (2006). Jauniešu valoda [Language of the Youth]. Rīga: LU Akadēmiskais apgāds, 193 lpp. (in Latvian).

6. Fend, H. (2000). Entwicklungspsychologie des Jugendalters. Ein Lehrbuch für pädagogische und psychologische Berufe. Opladen: Leske+Budrich, S. 523.

7. Ferchhoff, W. (1999). Jugend an der Wende vom 20. zum 21. Jahrhundert. Lebensformen und Lebensstile. Opladen: Leske+Budrich, S. 333.

8. Ferchhoff, W., Neubauer, G. (1997). Patchwork - Jugend. Eine Einführung in postmoderne Sichtweisen. Opladen: Leske+Budrich, S. 197.

9. Gaigala, A. (2007). Vai un käpēc jauniešiem cita valoda [Do Young People Speak Another Language and Why?]. Retrieved November 9, 2008, from http://www.satori.lv/raksts/1689/Austra_Gaigala/Nai_un_kapec_jauniesiem_cita_valoda

10. Hurrelmann, K. (1998). Einführung in die Sozialisationstheorie. Über den Zusammenhang von Sozialisationsstruktur und Persönlichkeit. Weinheim und Basel: Beltz, S. 301.

11. Kasten, H. (1999). Pubertät und Adoleszenz: wie Kinder heute erwachsen werden. München, Basel: Ernst Reinhardt, S. 224

12. Markus, D. (2003). Bērna valoda: no pirmà kliedziena lìdz pasakai [A Child's Language: From the First Cry to the Fairy-Tale]. Rīga: Rasa ABC, 143 Ipp. (in Latvian).

13. Markus, D. (2008). Latviešu bērnu valodas pētījumi: problēmas un risinājumi [Studies of the Language Spoken by Latvian Children: Problems and Solutions]. In: Letonikas otrais kongress. Valodniecibas raksti - 2 (136.145. Ipp.). Rīga: LZA (in Latvian).

14. Neuland, E. (2004). Jugendsprache und Standardsprache - Sprachgebrauch Jugendlicher in Deutschland. (Ergebnisse des DFG-Forschungsprojektes). Frankfurt/M., Berlin, Bern: Peter Lang.

15. Pedagóiijas terminu skaidrojošă vārdnīca [Explanatory Dictionary of Pedagogical Terms]. Rīga: Zvaigzne, 248 Ipp.(in Latvian).

16. Remschmidt, H. (1992). Adoleszenz. Entwicklung und Entwicklungskrisen im Jugendalter. Stuttgart, New York: Georg Thieme, S. 310.

17. Schäfers, B. (2001). Jugendsoziologie. Opladen: Leske+Budrich, S. 214.

18. Svence, G. (1999). Attīstïbas psiholoǵija [Developmental Psychology]. Rīga: Zvaigzne, 159 lpp. (in Latvian).

19. Zimmermann, P. (2000). Grundwissen Sozialisation. Opladen: Leske+Budrich, S. 144.

\section{Researcher Dr. philol. Laura Tidrike}

Child's Language Research Centre of Riga Teacher Training and Educational Management Academy University of Latvia

Address: Imantas 7. linija 1, Riga, LV-1083, Latvia

Phone: (+371) 67860682, (+371) 67034016

E-mail: laura.tidrike@lu.lv 